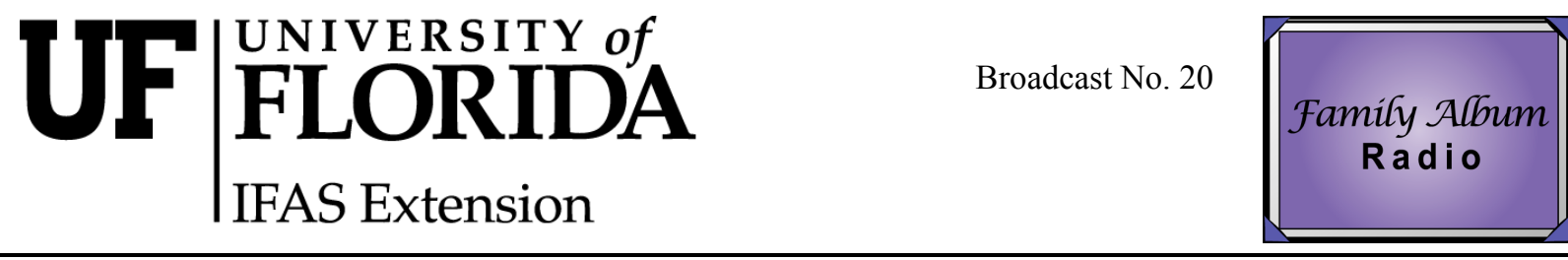

Transcribed from the Family Album Radio Program, a co-production of University of Florida IFAS Extension, the Department of Family, Youth and Community Sciences and of WUFT-FM. If you'd like to learn more, please visit our website at familyalbumradio.org

Listening, learning and living together, it's the science of life.

\section{Parenting After A Natural Disaster}

\section{Donna Davis and Suzanna Smith ${ }^{2}$}

Nobody ever said family life was a breeze ... yet few are prepared for the gale force impact that hurricanes can pack on even the healthiest of families.

This is a stressful time, and it's common for all family members to show signs of stress. Right after a natural disaster, parents and children may be tense and nervous, restless, and have trouble calming down. They may also experience stomachaches, headaches, and dizziness. Many people who are under strain from natural disasters feel fatigued and low in energy.

An event like a hurricane is frightening to children and adults. Children may show their fear by refusing to go back to school, misbehaving, and/or clinging to a parent. They may have trouble sleeping and want to sleep with a parent.

Family recovery will go more smoothly when the adults in the household can control their own feelings of stress, anxiety, and fear and do everything possible to help their children feel safe. A few suggestions may help parents at this difficult time:

Spend more time with your children. Let them stick by your side. Also, doing something fun and physical relieves tension. Reassure children that you care about them and encourage older children to talk about their feelings and thoughts. Answer their questions.

1. This document is FAR0001, one of a series of the Family Youth and Community Sciences Department, Florida Cooperative Extension Service, Institute of Food and Agricultural Sciences, University of Florida. Published August 2006. Reviewed by Kate Fogarty. Some scientific language from the original script has been modified to better serve the listener. The script published here represents the actual broadcast as heard on Family Album Radio. Visit the EDIS Web Site at http://edis.ifas.ufl.edu.

2. Donna Davis, Senior Producer, Family Album Radio and Suzanna Smith, Associate Professor, Human Development, Department of Family, Youth and Community Sciences, Cooperative Extension Service, Institute of Food and Agricultural Sciences, University of Florida, Gainesville FL 32611.

The Institute of Food and Agricultural Sciences (IFAS) is an Equal Employment Opportunity - Affirmative Action Employer authorized to provide research, educational information and other services only to individuals and institutions that function without regard to race, creed, color, religion, age, disability, sex, sexual orientation, marital status, national origin, political opinions or affiliations. For information on obtaining other extension publications, contact your county Cooperative Extension Service office. Florida Cooperative Extension Service / Institute of Food and Agricultural Sciences / University of Florida / Larry R. Arrington, Dean. 
Keep regular schedules for meals, playtime, and bed time as much as possible. This will help to restore order in the family's life.

More information about how to cope with a natural disaster can be found on our website at www.FamilyAlbumRadio.org

To listen to the radio broadcast:

http://radiosource.net/radio stories/paand.wav

http://radiosource.net/radio_stories/paand.mp3

\section{References}

Institute of Food and Agricultural Sciences. (1998). The Disaster Handbook.

Gainesville, FL. University of Florida.

American Psychological Association. (2004). Tips for recovering from disasters and other traumatic events.

NSW Health. (2000). Disaster Mental Health Response Handbook. Centre for Mental Health. North Sydney Australia. 